\title{
SOCIAL MEDIA ADOPTION AND EXPORT PERFORMANCE: EVIDENCE FROM TURKEY
}

\author{
DOI: 10.17261/Pressacademia.2021.1510 \\ PAP- V.14-2021(36)-p.137-138
}

Mine Aksoy ${ }^{1}$, Zelha Altinkaya ${ }^{2}$, Zekeriya Oguz Secme ${ }^{3}$

${ }^{1}$ Yalova University, Faculty of Economics and Administrative Sciences, Yalova, Turkey. maksoy@yalova.edu.tr, ORCID: 0000-0002-4773-1770

${ }^{2}$ Yalova University, Faculty of Economics and Administrative Sciences, Yalova, Turkey. zelha.altinkaya@yalova.edu.tr, ORCID: 0000-0002-6964-7182

${ }^{3}$ Yalova University, Faculty of Economics and Administrative Sciences, Yalova, Turkey. oguzsecme@yalova.edu.tr, ORCID: 0000-0003-0471-3211

\section{To cite this document}

Aksoy,M.,Altinkaya,Z. and Zekeriya O. Seçme (2021). Social media adoption and export performance : evidence from Turkey. PressAcademia Procedia (PAP), 14, 137-138.

Permanent link to this document: http://doi.org/10.17261/Pressacademia.2021.1510

Copyright: Published by PressAcademia and limited licensed re-use rights only.

\begin{abstract}
Purpose- The purpose of this study is to analyze the relationship between social media adoption (SMA) and export performance (EP) in Turkey as an emerging market economy. This paper also examines the role that the adoption of social media plays in firm export performance and whether this role is moderated by firm size.

Methodology- The study employs the panel tobit model to investigate the relation between SMA and EP. The Borsa Istanbul Manufacturing Index, comprised of 150 firms, constitutes our sample frame. The timeframe for our dataset covers the period of 2010-2020. While analyzing the determinants of EP, R\&D intensity, marketing intensity, firm size, firm age, internationalization age and sector are control variables, and SMA is independent variable. The SMA was proxied by Social Media Index (SMI), Facebook, Instagram, Twitter, and YouTube dummies. Following Slover-Linett and Stoner (2011), we choose a simple criterion to define an official social media presence. A social media presence was considered official if linked from the institutional website, directly from the homepage or from the secondary level of the website. SMI is defined as the sum of Facebook, Instagram, Twitter, and YouTube dummies. Facebook dummy assumes the value of '1' when the firm has a Facebook account in a particular year, or ' 0 ' otherwise. Instagram, Twitter and YouTube dummies were defined in the same way.

Findings- The analysis reveals that the coefficient for SMI is positive and statistically significant. The results also showed that the coefficient for the interaction between SMI and firm size is positive and significant. Moderation examines under what conditions, the SMI-EP relation varies. The firm size has a positive and significant moderating role on the relation between SMI and EP. Although, the coefficients for Facebook and Instagram are positive and significant, the coefficients for Twitter and Youtube are insignificant. The findings also indicate that while R\&D intensity is negatively and statistically significant, marketing intensity and firm size are positively, and statistically significant and internationalization age is negatively and statistically significant for firms with a high level of EP. We were unable to find support for an association between EP and firm age.

Conclusion- The results suggest a positive effect of social media adoption on export performance and this relationship is moderated by firm size. Turkish companies that adopt social media benefit from higher levels of export performance. The result of this study contributes to the existing literature pointing to the importance of social media adoption for exporting firms in emerging markets.
\end{abstract}

Keywords: Export performance, social media, facebook, twitter, Turkey, emerging economies.

JEL Codes: F10,F12, F13

\section{REFERENCES}

Abed, S.S., Dwivedi, Y.K., Williams, M.D.(2015). Social media as a bridge to e commerce adoption in SME: a systematic literature review. The Marketing Review, 15(1), 39-57.

Alarcon, M., Rialp, A., Josep Rialp (2015). The effect of social media adoption on exporting firms performance. Entrepreneurship in International Marketing, 25, 161-186.

Bartlett, D. (1926). Advertising for export trade. The Annals of the American Academy of Political and Social Science, 127, 186-190. 
Casetta, E. Monarca, U. Dileo, Berardino, C., M. Pini. (2019). The relationship between digital technologies and internationalisation. evidence from Italian SMEs. Industry and Innovation, 37, 311-339.

Cave,D, Hoffman,S.Joske, A. Ryan, Fergus, Elise Thomas (2019). Enabling \& exporting digital authoritarianism. Mapping China's technology giants. Australian Strategic Policy Institute. http://www.jstor.com/stable/resrep23072.8

Çavusgil, S. Tamer, Shaoming Zou, (1994). Marketing strategy-performance relationship: an investigation of the empirical link in export market ventures. Journal of Marketing, 58(1), 1-21.

Haller, S.A., I. Siedchiag, (2011). Determinants of ICT adoption: Evidence from firm level data. Applied Economics, 43(26), 3775-3788.

Markusen, J.R., Keith Maskus (2011). International Trade: Theory and Evidence.

Media Ajir and Bethany Vailliant (2018). Russian information warfare: implications for deterrence theory. Strategic Studies Quarterly, 12(3), 70-89.

Siegel, A. David, (2013). Social networks and the mass media. The American Political Science Review, 107(4), 786-805.

Simmie, J., Sennett, J., Wood, P., Dough Hart, (2002). Innovation in Europe: a tale of networks, knowledge and trade in five cities. Regional Studies, 36(1), 47-64.

Slover-Linett, C., Stoner, M., (2011). Succeeding with social media: Lessons from the first survey of social media in advancement. Retrieved from http://www.sloverlinett.com/files/mStoner-SloverLinett\%20White\%20Paper.pdfb

Tybout, James, (2001). Plant and Firm Level Evidence on New Trade Theories. NBER Working Paper No. 8418.

Zeriti, A., Robson, M.J, Spyropoulou S., Constantinos N. Leonidou. (2014). Sustainable export marketing strategy fit and performance. Journal of International Marketing, 22(4), 44-66. 